\title{
Potassium iodide, but not potassium iodate, as a potential protective agent against oxidative damage to membrane lipids in porcine thyroid
}

Magdalena Milczarek', Jan Stępniak, Andrzej Lewiński²,3 and Małgorzata Karbownik-Lewińska 1,3*

\begin{abstract}
Background: Fenton reaction $\left(\mathrm{Fe}^{2+}+\mathrm{H}_{2} \mathrm{O}_{2} \rightarrow \mathrm{Fe}^{3+}+{ }^{\cdot} \mathrm{OH}+\mathrm{OH}^{-}\right.$) is of special significance in the thyroid gland, as both its substrates, i.e. $\mathrm{H}_{2} \mathrm{O}_{2}$ and $\mathrm{Fe}^{2+}$, are required for thyroid hormone synthesis. Also iodine, an essential element supplied by the diet, is indispensable for thyroid hormone synthesis. It is well known that iodine affects red-ox balance. One of the most frequently examined oxidative processes is lipid peroxidation $(L P O)$, which results from oxidative damage to membrane lipids. Fenton reaction is used to experimentally induce lipid peroxidation. The aim of the study was to evaluate effects of iodine, used as potassium iodide $(\mathrm{KI})$ or potassium iodate $\left(\mathrm{KIO}_{3}\right)$, on lipid peroxidation in porcine thyroid homogenates under basal conditions and in the presence of Fenton reaction substrates.
\end{abstract}

Methods: Porcine thyroid homogenates were incubated in the presence of either $\mathrm{KI}(0.00005-500 \mathrm{mM})$ or $\mathrm{KIO}_{3}$ $(0.00005-200 \mathrm{mM})$, without or with addition of $\mathrm{FeSO}_{4}(30 \mu \mathrm{M})+\mathrm{H}_{2} \mathrm{O}_{2}(0.5 \mathrm{mM})$. Concentration of malondialdehyde + 4-hydroxyalkenals (MDA + 4-HDA) was measured spectrophotometrically, as an index of lipid peroxidation.

Results: Potassium iodide, only when used in the highest concentrations ( $\geq 50 \mathrm{mM})$, increased lipid peroxidation in concentration-dependent manner. In the middle range of concentrations (5.0; 10; 25; 50 and $100 \mathrm{mM}$ ) KI reduced Fenton reaction-induced lipid peroxidation, with the strongest protective effect observed for the concentration of 25 $\mathrm{mM}$. Potassium iodate increased lipid peroxidation in concentrations $\geq 2.5 \mathrm{mM}$. The damaging effect of $\mathrm{KIO}_{3}$ increased gradually from the concentration of $2.5 \mathrm{mM}$ to $10 \mathrm{mM}$. The strongest damaging effect was observed at the $\mathrm{KIO}_{3}$ concentration of $10 \mathrm{mM}$, corresponding to physiological iodine concentration in the thyroid. Potassium iodate in concentrations of 5-200 mM enhanced Fenton reaction-induced lipid peroxidation with the strongest damaging effect found again for the concentration of $10 \mathrm{mM}$.

Conclusions: Potassium iodide, used in doses generally recommended in iodide prophylaxis, may prevent oxidative damage to membrane lipids in this gland. Toxic effects of iodide overload may result from its prooxidative action. Potassium iodate does not possess any direct beneficial effects on oxidative damage to membrane lipids in the thyroid, which constitutes an additional argument against its utility in iodine prophylaxis.

Keywords: Potassium iodide, Potassium iodate, Thyroid, Lipid peroxidation, Ferrous ion, Hydrogen peroxide

\footnotetext{
* Correspondence: MKarbownik@hotmail.com

'Department of Oncological Endocrinology, Medical University of Łódź, 7/9

Żeligowski Street, Łódź 90-752, Poland

${ }^{3}$ Polish Mother's Memorial Hospital - Research Institute, 281/289, Rzgowska

Street, Łódź 93-338, Poland

Full list of author information is available at the end of the article
} 


\section{Background}

Iodine, an essential trace element, is indispensable for thyroid hormone synthesis in humans and animals [1]. The only natural source of iodine is the diet. However, in numerous areas in the world iodine supply from natural sources is inadequate, resulting in iodine deficiency disorders (IDD) $[2,3]$. Precisely elaborated programs of iodine prophylaxis were introduced in different countries to prevent IDD [4]. These programs are mainly based on salt iodization with the use of either potassium iodide (KI) or potassium iodate $\left(\mathrm{KIO}_{3}\right)$.

These two compounds are characterised by different chemical properties and some differencies in potential toxicity/safety. Iodate is more stable, as iodide is readily oxidized to iodine and lost by evaporation [5]. Whereas reliable methods are validated for quantifying $\mathrm{KIO}_{3}$ salt content, further validation is required for countries that use $\mathrm{KI}$ in salt iodization programs [6]. All other differences between $\mathrm{KIO}_{3}$ and $\mathrm{KI}$ suggest the superiority of the latter over the former. First, human iodine bioavailability from KI is higher than from $\mathrm{KIO}_{3}[7,8]$. Second, in biofortification of vegetables with iodine, KI was found to be much more effective than $\mathrm{KIO}_{3}[9,10]$.

In turn, according to some health authorities, the safety of $\mathrm{KIO}_{3}$ to humans and animals is not completely documented and in 2002 the French Agency for Food Safety [11] did even question the use of $\mathrm{KIO}_{3}$ instead of $\mathrm{KI}$ in iodine prophylaxis. Therefore, several experimental studies have been performed to clarify this issue. For example, it has been shown in experimental studies that $\mathrm{KIO}_{3}$ does not reveal genotoxic effects [12]. Also comparative studies of the oxidative properties of iodate and other halogenate salts, such as bromate and chlorate, have shown that iodate would be of low, if any, genotoxic potential [13]. It is worth mentioning that both, $\mathrm{KI}$ and $\mathrm{KIO}_{3}$, reveal similar effectiveness as blockers of radioiodine uptake by the thyroid in rats [14].

Nevertheless, according to similar effectiveness in iodine prophylaxis, both $\mathrm{KI}$ and $\mathrm{KIO}_{3}$ were initially proved to be used for fortifying salt by the Joint WHO/FAO Expert Committee on Food Additives and Contaminants [15] and they are, along with other iodine salts, still admitted to be added to foods, including food supplements [16].

It is well known that iodine affects red-ox balance [17]. It is especially known for its excellent antioxidative properties in physiological conditions $[18,19]$. However, prooxidative effects of iodine were also demonstrated in experimental models. For example, in studies in vivo, iodine - given as iodide - expectedly increased MDA level in the rat thyroid and liver [20], or it increased Schiff's bases in rat lung and liver [21] and - when given as $\mathrm{KIO}_{3}$ - in mice liver [22]. The latter change was accompanied by the increased activities of antioxidative enzymes, such as glutathione peroxidase and superoxide dismutase, but only after longer time
(3 months) of iodine exposure [22]. Thus, the balance between anti- and prooxidative effects of iodine depends on different factors, such as iodine dose/concentration or the time of action.

However, anti- or prooxidative effects of iodine on the thyroid gland with relation to iodine source, i.e. a chemical compound containing iodine, have never been examined in vitro, thus under conditions reflecting direct effects of these compounds on thyroid follicular cells.

Fenton reaction $\left(\mathrm{Fe}^{2+}+\mathrm{H}_{2} \mathrm{O}_{2} \rightarrow \mathrm{Fe}^{3+}+{ }^{\circ} \mathrm{OH}+\mathrm{OH}^{-}\right)$, being the basic reaction of oxidative stress, is of special significance in the thyroid gland, as both its substrates, i.e. $\mathrm{H}_{2} \mathrm{O}_{2}$ and $\mathrm{Fe}^{2+}$, are required for thyroid hormone synthesis [23]. One of the most frequently examined oxidative processes is lipid peroxidation (LPO), which results from oxidative damage to membrane lipids. Bivalent iron $\left(\mathrm{Fe}^{2+}\right)$ and $\mathrm{H}_{2} \mathrm{O}_{2}$, which initiate Fenton reaction, have been frequently used to experimentally induce lipid peroxidation in different tissues [24-29], the thyroid gland included [30,31]. Also oxidative damage to nuclear and mitochondrial DNA has been induced by Fenton reaction substrates [32].

The aim of the study was to evaluate effects of iodine, used as potassium iodide (KI) or potassium iodate $\left(\mathrm{KIO}_{3}\right)$, on lipid peroxidation in porcine thyroid homogenates under basal conditions and in the presence of Fenton reaction substrates.

Preliminary results of the study were presented (as a poster presentation) during International and European Congress of Endocrinology in 2012 [33].

\section{Methods}

\section{Ethical approval}

The procedures, used in the study, were approved by the Ethics Committee of the Medical University of Lodz, Poland.

\section{Chemicals}

Potassium iodide (KI), potassium iodate $\left(\mathrm{KIO}_{3}\right)$, ferrous sulfate $\left(\mathrm{FeSO}_{4}\right)$ and hydrogen peroxide $\left(\mathrm{H}_{2} \mathrm{O}_{2}\right)$ were purchased from Sigma (St. Louis, MO). The ALDetect Lipid Peroxidation Assay Kit was obtained from Enzo Life Sciences, Inc. (Zandhoven, Belgium). MilliQ-purified $\mathrm{H}_{2} \mathrm{O}$ was used for preparing all solutions. All the used chemicals were of analytical grade and came from commercial sources.

\section{Animals}

Porcine thyroids were collected from forty five (45) animals at a slaughter-house, frozen on solid $\mathrm{CO}_{2}$, and stored at $-80^{\circ} \mathrm{C}$ until assay. Each experiment was repeated three to five times. Therefore, three to five tissue pools were prepared, with nine (9) thyroid glands used for each homogenate pool. 


\section{Assay of lipid peroxidation}

Thyroid tissue was homogenized in ice cold $20 \mathrm{mM}$ Tris- $\mathrm{HCl}$ buffer $(\mathrm{pH}=7.4)(10 \%, \mathrm{w} / \mathrm{v})$, and then incubated for $30 \mathrm{~min}$ at $37^{\circ} \mathrm{C}$ in the presence of examined substances. Porcine thyroid homogenates were incubated in the presence of either KI $(500 ; 250 ; 100 ; 50 ; 25$; $10 ; 5.0 ; 2.5 ; 1.0 ; 0.5 ; 0.25 ; 0.1 ; 0.05 ; 0.025 ; 0.01 ; 0.005$; $0.0025 ; 0.001 ; 0.0005 ; 0.00025 ; 0.0001 ; 0.00005 \mathrm{mM})$ or $\mathrm{KIO}_{3}(200 ; 150 ; 100 ; 50 ; 25 ; 10 ; 5.0 ; 2.5 ; 1.0 ; 0.5 ; 0.25$; $0.1 ; 0.05 ; 0.025 ; 0.01 ; 0.005 ; 0.0025 ; 0.001 ; 0.0005$; $0.00025 ; 0.0001 ; 0.00005 \mathrm{mM}$ ) without or with addition of Fenton reaction substrates, i.e. $\mathrm{FeSO}_{4}(30 \mu \mathrm{M})+$ $\mathrm{H}_{2} \mathrm{O}_{2}(0.5 \mathrm{mM})$, or with addition of $\mathrm{FeSO}_{4}(30 \mu \mathrm{M})$ only. According to different solubility of $\mathrm{KI}$ and $\mathrm{KIO}_{3}$, different highest concentrations of these compounds were used in the study. Eight (8) separate experiments were performed, as it is specified in the Results section. The reactions were stopped by cooling the samples on ice. Each experiment was run in duplicate and repeated three to five times.

\section{Measurement of lipid peroxidation products}

The concentrations of malondialdehyde +4 -hydroxyalkenals (MDA + 4-HDA), as an index of lipid peroxidation, were measured in thyroid homogenates, with the ALDetect Lipid Peroxidation Assay Kit. The homogenates were centrifuged at 3,000 x g for $10 \mathrm{~min}$ at $4^{\circ} \mathrm{C}$. After obtaining supernatant, each experiment was carried out in duplicate. The supernatant $(200 \mu \mathrm{l})$ was mixed with $650 \mu \mathrm{l}$ of a methanol: acetonitrile $(1: 3, \mathrm{v} / \mathrm{v})$ solution, containing a chromogenic reagent, N-methyl-2-phenylindole, and vortexed. Following the addition of $150 \mu \mathrm{l}$ of methanesulfonic acid $(15.4 \mathrm{M})$, the incubation was carried out at $45^{\circ} \mathrm{C}$ for $40 \mathrm{~min}$. The reaction between MDA + 4-HDA and Nmethyl-2-phenylindole yields a chromophore, which is spectrophotometrically measured at the absorbance of $586 \mathrm{~nm}$, using a solution of $10 \mathrm{mM}$ 4-hydroxynonenal as the standard. The level of lipid peroxidation is expressed as the amount of MDA + 4-HDA (nmol) per mg protein. Protein was measured, using Bradford's method [34], with bovine albumin as the standard.

\section{Statistical analyses}

Results are expressed as means $\pm \mathrm{SE}$. The data were statistically analyzed, using a one-way analysis of variance (ANOVA), followed by the Student-Neuman-Keuls' test. The level of $\mathrm{p}<0.05$ was accepted as statistically significant.

\section{Results}

Two examined substances, i.e. $\mathrm{KI}$ and $\mathrm{KIO}_{3}$, did not reveal the same effects on oxidative damage to membrane lipids in porcine thyroid homogenates, both under basal conditions and in the presence of Fenton reaction substrates.
Potassium iodide, when used in the highest concentrations $(\geq 50 \mathrm{mM})$, did increase lipid peroxidation in concentrationdependent manner. In turn, KI in concentrations $\leq 25 \mathrm{mM}$ did not affect lipid peroxidation (Figure 1).

When KI was used together with $\mathrm{Fe}^{2+}+\mathrm{H}_{2} \mathrm{O}_{2}$, the following results were obtained. Potassium iodide used in the middle range of concentrations $(5.0 ; 10 ; 25 ; 50$ and $100 \mathrm{mM})$ reduced Fenton reaction-induced lipid peroxidation, with the strongest protective effect observed for the concentration of $25 \mathrm{mM}$, which completely prevented experimentally-induced lipid peroxidation (Figure 2). Interestingly, KI either in higher $(\geq 250 \mathrm{mM})$ or lower $(\leq 2.5 \mathrm{mM})$ concentrations did not affect significantly Fenton reaction-induced lipid peroxidation, which means that the level of lipid peroxidation in the presence of $\mathrm{KI}(\geq 250 \mathrm{mM}$ or $\leq 2.5 \mathrm{mM})$ plus $\mathrm{Fe}^{2+}+\mathrm{H}_{2} \mathrm{O}_{2}$ was the same as in the presence of $\mathrm{Fe}^{2+}+\mathrm{H}_{2} \mathrm{O}_{2}$ only (Figure 2).

Subsequently, to compare prooxidative effects of KI alone to prooxidative effects of KI plus Fenton reaction substrates, the separate experiment was performed, in which thyroid homogenates were incubated in the presence of KI (in concentrations of $0.25-500 \mathrm{mM}$ ) alone or together with $\mathrm{Fe}^{2+}+\mathrm{H}_{2} \mathrm{O}_{2}$ (Figure 3). The level of lipid peroxidation was significantly higher when KI (in concentrations $\leq 100$ $\mathrm{mM}$ ) was used together with $\mathrm{Fe}^{2+}+\mathrm{H}_{2} \mathrm{O}_{2}$. However, KI did not enhanced Fenton reaction-induced lipid peroxidation (Figure 3), which is in agreement with results shown in Figure 2.

In our earlier study [31], $\mathrm{Fe}^{2+}$ used alone (i.e. as only one of Fenton reaction substrates), in opposite to $\mathrm{H}_{2} \mathrm{O}_{2}$,

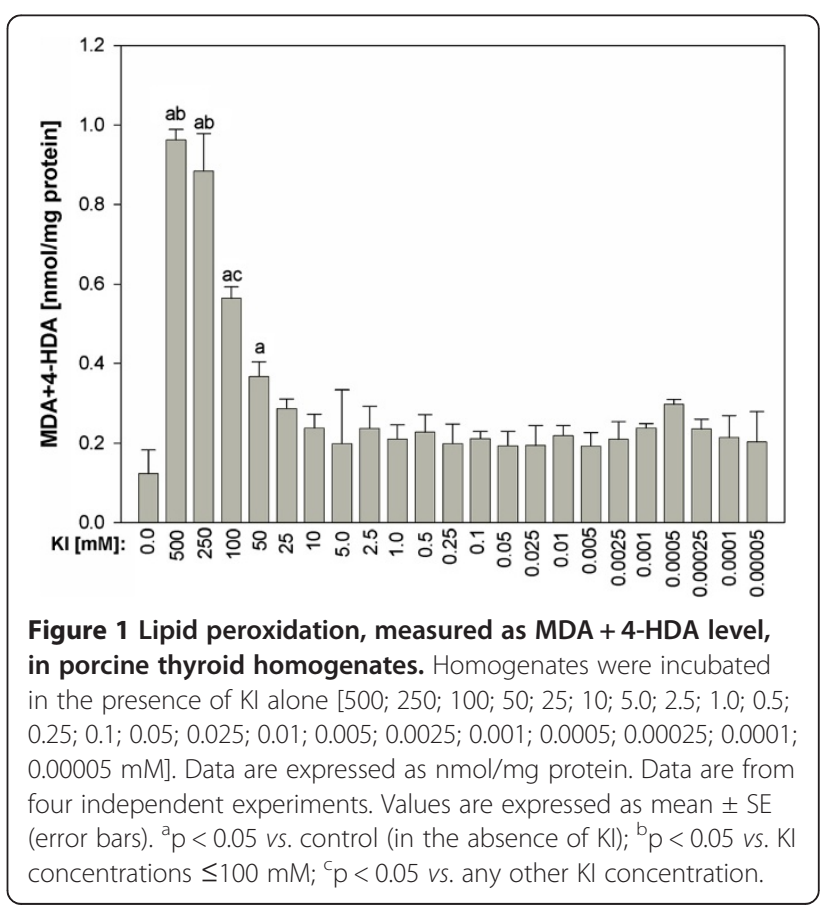




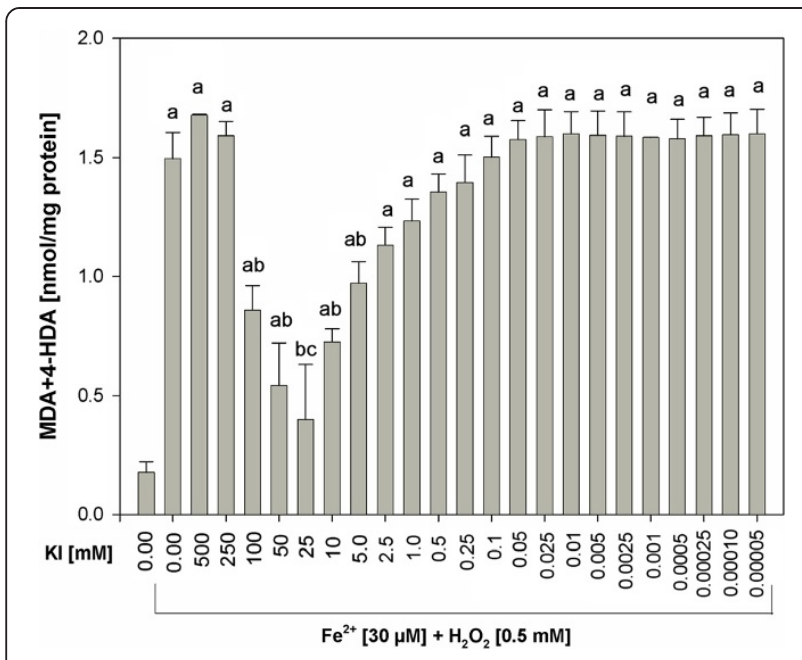

Figure 2 Lipid peroxidation, measured as MDA + 4-HDA level, in porcine thyroid homogenates. Homogenates were incubated in the presence of KI $[500 ; 250 ; 100 ; 50 ; 25 ; 10 ; 5.0 ; 2.5 ; 1.0 ; 0.5 ; 0.25 ; 0.1 ; 0.05$; $0.025 ; 0.01 ; 0.005 ; 0.0025 ; 0.001 ; 0.0005 ; 0.00025 ; 0.0001 ; 0.00005 \mathrm{mM}]$ and, additionally, in the presence of both Fenton reaction substrates, namely in the presence of $\mathrm{FeSO}_{4}[30 \mu \mathrm{M}]$ plus $\mathrm{H}_{2} \mathrm{O}_{2}[0.5 \mathrm{mM}]$. Data are expressed as $\mathrm{nmol} / \mathrm{mg}$ protein. Data are from three independent experiments. Values are expressed as mean $\pm \mathrm{SE}$ (error bars). ${ }^{\mathrm{a}} \mathrm{p}<0.05 \mathrm{vs}$. control (in the absence of $\mathrm{Kl}$ or $\mathrm{Fe}^{2+}+\mathrm{H}_{2} \mathrm{O}_{2}$ ) $;{ }^{b} \mathrm{p}<0.05$ vs. $\mathrm{Fe}^{2+}+\mathrm{H}_{2} \mathrm{O}_{2}$, vs. $\mathrm{Kl}[500 \mathrm{mM}]+\mathrm{Fe}^{2+}+\mathrm{H}_{2} \mathrm{O}_{2}$, vs. Kl $[250 \mathrm{mM}]+\mathrm{Fe}^{2+}+\mathrm{H}_{2} \mathrm{O}_{2} ;{ }^{c} \mathrm{p}<0.05$ vs. Kl $[100 \mathrm{mM}]+\mathrm{Fe}^{2+}+\mathrm{H}_{2} \mathrm{O}_{2}$.

induced lipid peroxidation in thyroid homogenates. Therefore, in the present study we have performed the additional experiment with use of KI (in concentrations of 0.25-500 $\mathrm{mM}$ ) alone or together with $\mathrm{Fe}^{2+}$ (Figure 4). No significant differences in lipid peroxidation were found for respective concentrations of KI in the presence or in the absence of $\mathrm{Fe}^{2+}$ (Figure 4).

In the opposite to $\mathrm{KI}, \mathrm{KIO}_{3}$ revealed, depending on the concentration or the presence/absence of $\mathrm{Fe}^{2+}+\mathrm{H}_{2} \mathrm{O}_{2}$, either no protective effect at all or even strong prooxidative action (Figures 5 and 6). When $\mathrm{KIO}_{3}$ was used alone, it did increase lipid peroxidation in concentrations $\geq 2.5 \mathrm{mM}$ (Figure 5). The damaging effect of $\mathrm{KIO}_{3}$ increased gradually from the concentration of $2.5 \mathrm{mM}$ to $10 \mathrm{mM}$ and, then, it decreased again gradually, however still being significantly stronger at the highest used $\mathrm{KIO}_{3}$ concentration $(200 \mathrm{mM})$ than in control (Figure 5). The strongest damaging effect to membrane lipids was observed at the $\mathrm{KIO}_{3}$ concentration of $10 \mathrm{mM}$ (Figure 5).

When $\mathrm{KIO}_{3}$ was used together with $\mathrm{Fe}^{2+}+\mathrm{H}_{2} \mathrm{O}_{2}$, the following results were obtained. Potassium iodate enhanced Fenton reaction-induced lipid peroxidation, when it was used in concentrations of $5 \mathrm{mM}$ to $200 \mathrm{mM}$, with the strongest damaging effect of $\mathrm{KIO}_{3}$ found again for the concentration of $10 \mathrm{mM}$ (Figure 6). Concentrationdependent effects of $\mathrm{KIO}_{3}$ used together with Fenton

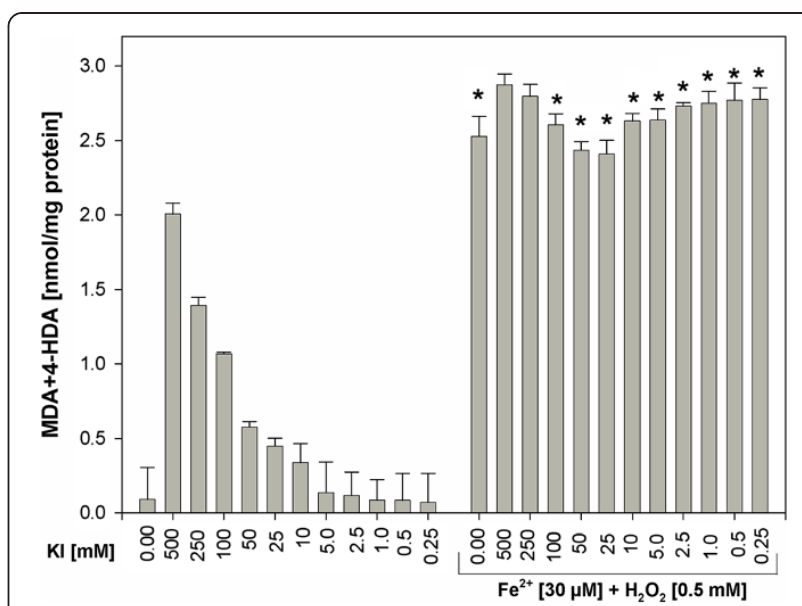

Figure 3 Lipid peroxidation, measured as MDA + 4-HDA level, in porcine thyroid homogenates. Homogenates were incubated in the presence of Kl alone $[500 ; 250 ; 100 ; 50 ; 25 ; 10 ; 5.0 ; 2.5 ; 1.0 ; 0.5 ; 0.25$ $\mathrm{mM}]$ or in the presence of $\mathrm{KI}[500 ; 250 ; 100 ; 50 ; 25 ; 10 ; 5.0 ; 2.5 ; 1.0 ; 0.5$; $0.25 \mathrm{mM}$ ] together with both substrates of Fenton reaction, namely in the presence of $\mathrm{FeSO}_{4}[30 \mu \mathrm{M}]$ plus $\mathrm{H}_{2} \mathrm{O}_{2}[0.5 \mathrm{mM}]$. Data are expressed as $\mathrm{nmol} / \mathrm{mg}$ protein. Data are from three independent experiments. Values are expressed as mean \pm SE (error bars). ${ }^{*} p<0.05$ vs. respective concentration of $\mathrm{Kl}$ alone (i.e. in the absence of $\mathrm{Fe}^{2+}+\mathrm{H}_{2} \mathrm{O}_{2}$ ).

reaction substrates were similar to those caused by $\mathrm{KIO}_{3}$ alone (compare Figures 5 and 6 ).

In comparative experiment (i.e. in the presence and in the absence of Fenton reaction substrates), the addition of $\mathrm{Fe}^{2+}+\mathrm{H}_{2} \mathrm{O}_{2}$ enhanced $\mathrm{KIO}_{3}$-induced lipid peroxidation, but only for $\mathrm{KIO}_{3}$ concentration $\leq 10 \mathrm{mM}$ ) (Figure 7). Strong

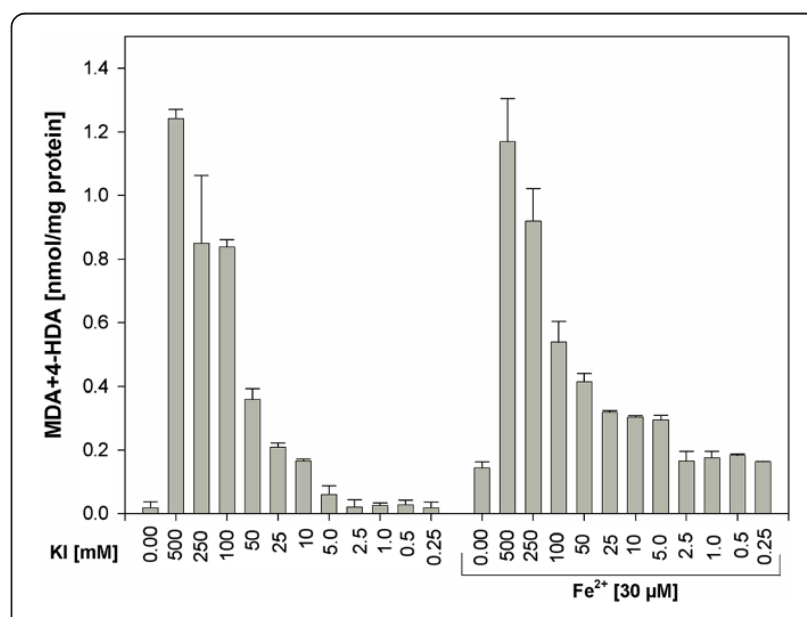

Figure 4 Lipid peroxidation, measured as MDA + 4-HDA level, in porcine thyroid homogenates. Homogenates were incubated in the presence of Kl alone $[500 ; 250 ; 100 ; 50 ; 25 ; 10 ; 5.0 ; 2.5 ; 1.0 ; 0.5 ; 0.25$ $\mathrm{mM}]$ or in the presence of KI $[500 ; 250 ; 100 ; 50 ; 25 ; 10 ; 5.0 ; 2.5 ; 1.0 ; 0.5 ; 0.25$ $\mathrm{mM}$ ] together with one substrate of Fenton reaction, namely in the presence of $\mathrm{FeSO}_{4}[30 \mu \mathrm{M}]$. Data are expressed as $\mathrm{nmol} / \mathrm{mg}$ protein. Data are from three independent experiments. Values are expressed as mean \pm SE (error bars). No statistical differences between respective concentrations of $\mathrm{KI}$ (i.e. in the presence and in the absence of $\mathrm{Fe}^{2+}$ ) were found. 


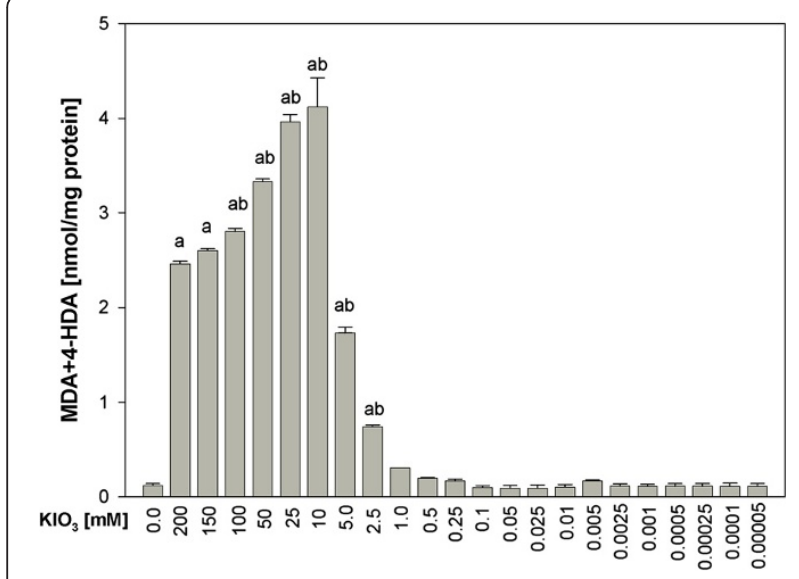

Figure 5 Lipid peroxidation, measured as MDA + 4-HDA level, in porcine thyroid homogenates. Homogenates were incubated in the presence of $\mathrm{KIO}_{3}$ alone $[200 ; 150 ; 100 ; 50 ; 25 ; 10 ; 5.0 ; 2.5 ; 1.0$; $0.5 ; 0.25 ; 0.1 ; 0.05 ; 0.025 ; 0.01 ; 0.005 ; 0.0025 ; 0.001 ; 0.0005 ; 0.00025$; $0.0001 ; 0.00005 \mathrm{mM}$. Data are expressed as nmol/mg protein. Data are from five independent experiments. Values are expressed as mean \pm SE (error bars). ${ }^{a} p<0.05$ vs. control (in the absence of $\mathrm{KIO}_{3}$ ), ${ }^{b} \mathrm{p}<0.05$ vs. any other $\mathrm{KIO}_{3}$ concentration.

prooxidative effects of $\mathrm{KIO}_{3}$ in concentrations $\geq 25 \mathrm{mM}$ was not enhanced by Fenton reaction substrates (Figure 7).

In turn, no significant differences were found for respective concentrations of $\mathrm{KIO}_{3}$ in the presence or in the absence of $\mathrm{Fe}^{2+}$ (Figure 8).

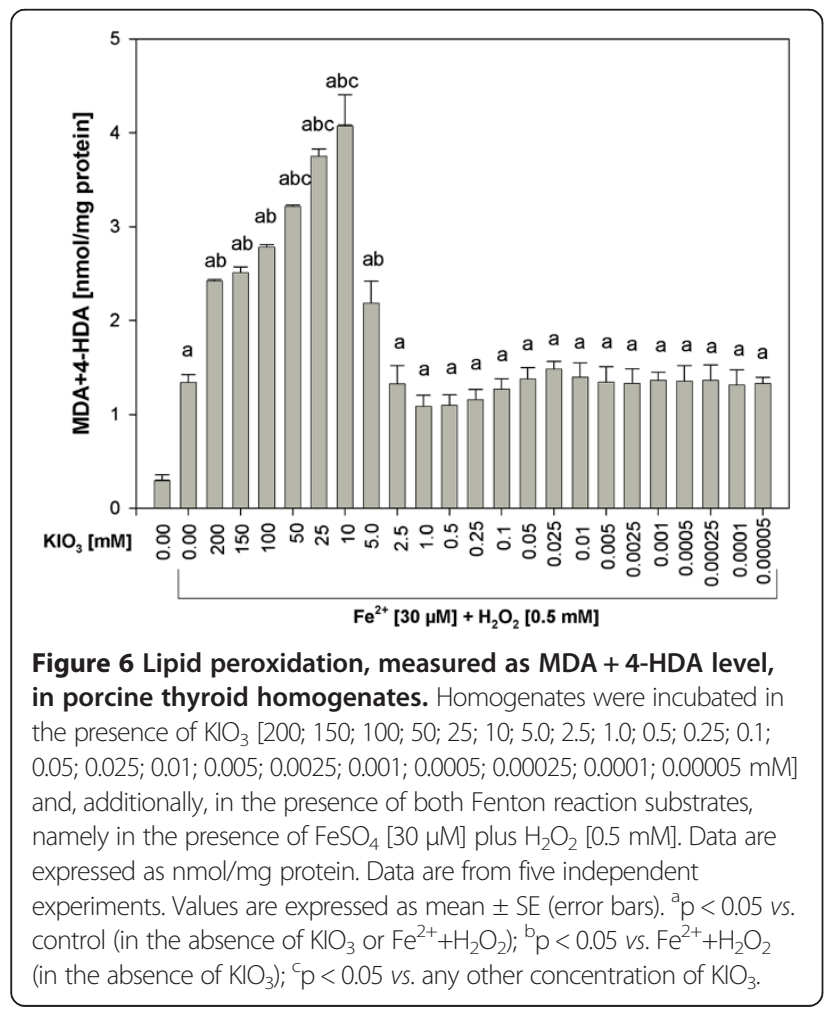

\section{Discussion}

Molar concentrations of $\mathrm{KI}$ and $\mathrm{KIO}_{3}$ were calculated in the present study with regard to whole compounds. Among chemical elements forming either $\mathrm{KI}$ or $\mathrm{KIO}_{3}$, iodine is characterized by the highest molecular mass - much higher than potassium $(\mathrm{K})$ and oxygen $(\mathrm{O})$, thus it constitutes the crucial part of both compounds concerning their molecular masses, i.e. iodine constitutes $76.45 \%$ of molecular mass of $\mathrm{KI}$, and in case of $\mathrm{KIO}_{3}$ it constitutes $59.30 \%$ of the molecular mass of this compound. In turn, the molecular mass of KI constitutes $77.57 \%$ of that one of $\mathrm{KIO}_{3}$, so the molecular masses of these two compounds are of the same order of magnitude. Therefore, concentrations of $\mathrm{KI}$ and of $\mathrm{KIO}_{3}$, calculated in the present study, may be used in comparative analyses either of effects of iodide ions $\left(\mathrm{I}^{-}\right)$formed from both $\mathrm{KI}$ and $\mathrm{KIO}_{3}$, or of effects of the whole compounds, i.e. KI and $\mathrm{KIO}_{3}$.

It is worth mentioning that in vitro KI treatment of the thyroid cell line $\mathrm{PCCl}_{3}$ resulted in the increased reactive oxygen species production [35]. Similar effect has not been evaluated after $\mathrm{KIO}_{3}$ treatment.

Only few studies have been performed till now to compare effects of iodine present in two different sources, namely in $\mathrm{KI}$ and $\mathrm{KIO}_{3}$. No differences were found between tissue (the thyroid gland, liver, kidney, muscle, abdominal fat tissue and skin) iodine content or blood thyroid hormone concentrations after in vivo treatment with high doses of either $\mathrm{KI}$ or $\mathrm{KIO}_{3}$ [8]. In similar in vivo model the same group of authors evaluated some parameters of oxidative stress [36]. Different compounds of iodine, i.e. $\mathrm{KI}$ or $\mathrm{KIO}_{3}$, have

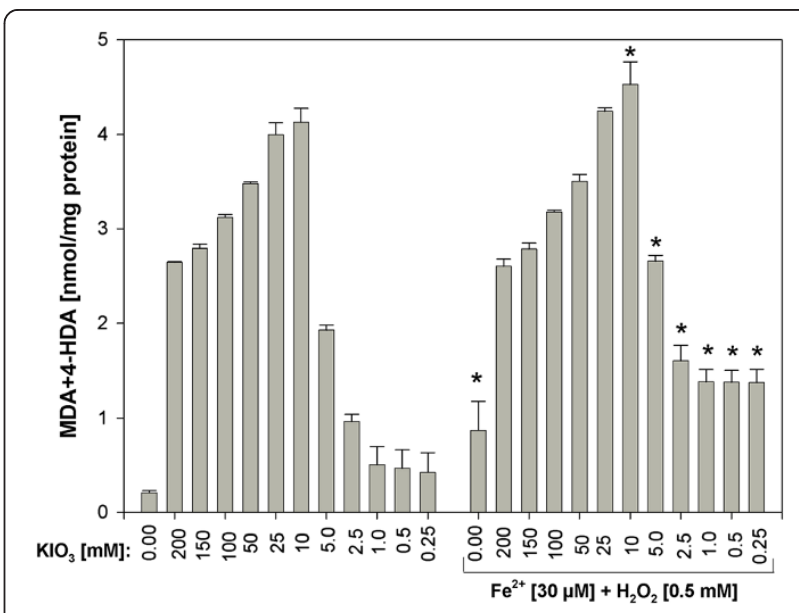

Figure 7 Lipid peroxidation, measured as MDA + 4-HDA level, in porcine thyroid homogenates. Homogenates were incubated in the presence of $\mathrm{KIO}_{3}$ alone $[200 ; 150 ; 100 ; 50 ; 25 ; 10 ; 5.0 ; 2.5 ; 1.0 ; 0.5 ; 0.25$ $\mathrm{mM}]$ or in the presence of $\mathrm{KIO}_{3}[200 ; 150 ; 100 ; 50 ; 25 ; 10 ; 5.0 ; 2.5 ; 1.0 ; 0.5$; $0.25 \mathrm{mM}$ ] together with both substrates of Fenton reaction, namely in the presence of $\mathrm{FeSO}_{4}[30 \mu \mathrm{M}]$ plus $\mathrm{H}_{2} \mathrm{O}_{2}[0.5 \mathrm{mM}]$. Data are expressed as $\mathrm{nmol} / \mathrm{mg}$ protein. Data are from three independent experiments. Values are expressed as mean $\pm \mathrm{SE}$ (error bars). ${ }^{*} \mathrm{p}<0.05 \mathrm{vs}$. respective concentration of $\mathrm{KIO}_{3}$ alone (i.e. in the absence of $\mathrm{Fe}^{2+}+\mathrm{H}_{2} \mathrm{O}_{2}$ ). 


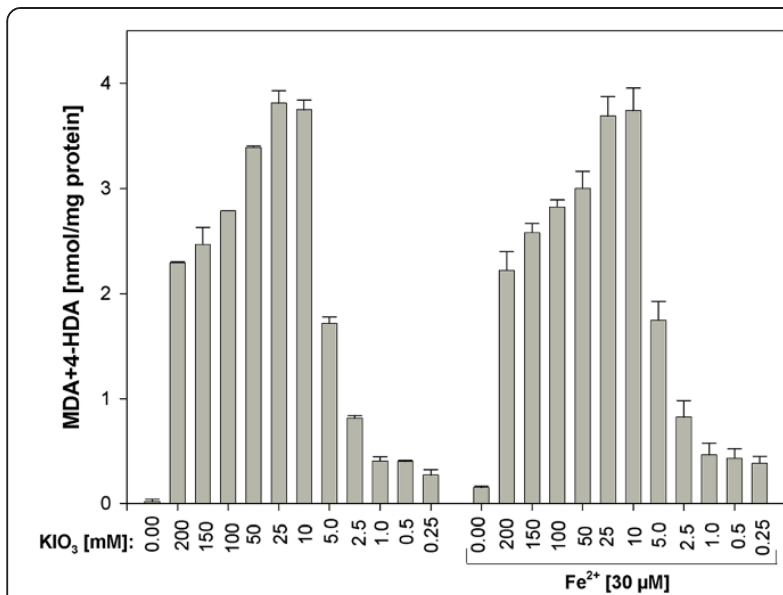

Figure 8 Lipid peroxidation, measured as MDA + 4-HDA level, in porcine thyroid homogenates. Homogenates were incubated in the presence of $\mathrm{KIO}_{3}$ alone $[200 ; 150 ; 100 ; 50 ; 25 ; 10 ; 5.0 ; 2.5 ; 1.0$; $0.5 ; 0.25 \mathrm{mM}]$ or in the presence of $\mathrm{KIO}_{3}[200 ; 150 ; 100 ; 50 ; 25 ; 10$; $5.0 ; 2.5 ; 1.0 ; 0.5 ; 0.25 \mathrm{mM}$ ] together with one substrate of Fenton reaction, namely in the presence of $\mathrm{FeSO}_{4}[30 \mu \mathrm{M}]$. Data are expressed as $\mathrm{nmol} / \mathrm{mg}$ protein. Data are from three independent experiments. Values are expressed as mean \pm SE (error bars). No statistical differences between respective concentrations of KI (i.e. in the presence and in the absence of $\mathrm{Fe}^{2+}$ ) were found.

similar effects on lipid peroxidation level (measured as MDA concentration) in the liver and the muscle, however certain differences were observed concerning mRNA expressions or the activities of antioxidative enzymes in different tissues [36]. However, such comparative studies have not been performed under in vitro conditions. The present study is the first one in which KI was found to be superior to $\mathrm{KIO}_{3}$ in the thyroid gland concerning oxidative damage to macromolecules.

More favourable effects of $\mathrm{KI}$ comparing to $\mathrm{KIO}_{3}$ were observed both, when each of these compounds was used separately or together with Fenton reaction substrates. Concerning the first situation, both $\mathrm{KI}$ and $\mathrm{KIO}_{3}$ revealed when used in high concentrations - damaging effects to membrane lipids in the thyroid. However, the difference between these unfavourable actions of $\mathrm{KI}$ and $\mathrm{KIO}_{3}$ was crucial. Namely, the damaging effect of KI decreased gradually with decreasing concentrations of this compound and these undesired effects were not observed for concentrations below $50 \mathrm{mM}$, thus concentrations corresponding to inorganic iodine level normally present in the thyroid under physiological conditions. On the basis of experimental findings [37-39] the concentration of inorganic iodine in the human or rat thyroid was calculated by the authors of the present work to be approx. $9 \mathrm{mM}$. Taking into account close similarity between human and porcine thyroid in terms of thyroid volume and of thyroid hormone synthesis with all elements and all steps of this process [40], it may be estimated that iodine concentration in porcine thyroid (used in the present study) is at similar level. Thus, the concentrations of KI resulting in thyroid level of inorganic iodine close to that observed under physiological conditions do not reveal prooxidative effects, at least in terms of oxidative damage to membrane lipids.

In opposite, when $\mathrm{KIO}_{3}$ was used alone, the highest lipid peroxidation was found for its concentration of $10 \mathrm{mM}$, thus corresponding to the physiological concentration in the thyroid, which was calculated to be $9 \mathrm{mM}$. It should be recalled that the same concentration of KI did not increase the level of lipid peroxidation (compare Figures 1 and 2).

When $\mathrm{KI}$ or $\mathrm{KIO}_{3}$ were added to the incubation medium together with Fenton reaction substrates, KI appeared to be also superior to $\mathrm{KIO}_{3}$ concerning their influence on lipid peroxidation in the thyroid gland. Whereas KI in concentrations of 5-100 $\mathrm{mM}$ (Figure 2), i.e. corresponding to physiological concentrations of inorganic iodine, diminished experimentally-induced lipid peroxidation, $\mathrm{KIO}_{3}$ did not reveal any protective action (Figure 5). Additionally, $\mathrm{KI}$ in concentration of $25 \mathrm{mM}$, thus being one order of magnitude higher than physiological iodine concentration, completely prevented Fenton reaction-induced lipid peroxidation. In turn, $\mathrm{KIO}_{3}$ enhanced Fenton reaction-induced lipid peroxidation, when it was used in concentrations of 5 $\mathrm{mM}$ to $200 \mathrm{mM}$, with the strongest damaging effect of $\mathrm{KIO}_{3}$ found again for the concentration of $10 \mathrm{mM}$ (Figure 6).

Additionally it is clearly visible that prooxidative effects of KI was enhanced by Fenton reaction substrates. At the same time the damaging effects of $\mathrm{KIO}_{3}$ were so strong that they were only weakly enhanced by Fenton reaction substrates (compare Figures 1 and 2, Figures 5 and 6, Figures 3 and 7). These comparative analyses reveal additionally the superiority of $\mathrm{KI}$ over $\mathrm{KIO}_{3}$.

Ferrous ion $\left(\mathrm{Fe}^{2+}\right)$, which was in our earlier study [31] documented to induce lipid peroxidation in the thyroid gland, when it was used as only one of Fenton reaction substrates, did not modify significantly in the present study the effect of either $\mathrm{KI}$ or of $\mathrm{KIO}_{3}$. This is probably due to the fact that prooxidative effects of $\mathrm{Fe}^{2+}$ alone is clearly weaker than those ones caused by both Fenton reaction substrates [31]. Potential mechanisms of differences between $\mathrm{KI}$ and $\mathrm{KIO}_{3}$ effects on lipid peroxidation in thyroid homogenates, observed in the present study, should be discussed. Thus, the following explanation is proposed.

The reduction of $\mathrm{IO}_{3}^{-}$, the process occurring when the tissue is exposed to $\mathrm{KIO}_{3}$, requires the time and energy and possibly it is associated with unfavorable oxidative reactions and the damaging effects.

In turn, $\mathrm{KIO}_{3}$ belongs to halogenate salts, which are known for their potentially toxic effects $[5,13,41]$. In our earlier studies, one of halogenate salts, namely potassium bromate $\left(\mathrm{KBrO}_{3}\right)$, being classified as carcinogen (group $2 \mathrm{~B}$ according to IARC 1986 [42]), was shown to exert damaging effect to membrane lipids in porcine thyroid under 
in vitro $(5 \mathrm{mM})$ and in vivo conditions [43]. Thus, $\mathrm{KBrO}_{3}$ and $\mathrm{KIO}_{3}$ increased lipid peroxidation in porcine thyroid homogenates when used in the same range of concentrations. At the same time, iodine used as KI (in concentrations $\leq 25 \mathrm{mM}$ ) did not reveal in the present study any toxic effects to membrane lipids and even it prevented experimentally induced lipid peroxidation, when used in the same range of concentrations (5-100 mM).

However, from among three halogenate salts, i.e. iodate, bromate and chlorate, the first one is characterized by the lowest redox potential. Therefore, $\mathrm{KIO}_{3}$ seems to be potentially less toxic than bromate and chlorate, at least when oxidative mechanisms are considered.

Our study was performed under in vitro conditions and, therefore, it cannot be extrapolated directly into in vivo conditions, especially that $\mathrm{IO}_{3}^{-}$is reduced to $\mathrm{I}^{-}$before approaching the thyroid cell. However, our study is the first one which supports the statement that the use of KI in iodine prophylaxis is more safe than of $\mathrm{KIO}_{3}$, in terms of their influence on oxidative damage to macromolecules. Additionally, not only the thyroid gland should be considered in the aspect of prooxidative effects of $\mathrm{KIO}_{3}$ but, more importantly, other tissues, in particular digestive system, which is approached by $\mathrm{KIO}_{3}$ earlier, i.e. immediately after exposure to this salt.

\section{Conclusions}

Potassium iodide, used in doses generally recommended in iodide prophylaxis, thus resulting in physiological iodine concentration in the thyroid, may prevent oxidative damage to membrane lipids in this gland. Toxic effects of iodide overload may result from its prooxidative action. Potassium iodate does not possess any direct beneficial effects on oxidative damage to membrane lipids in the thyroid, which constitutes an additional argument against its utility in iodine prophylaxis.

\section{Competing interests}

Authors declare that they have no competing interests.

\section{Authors' contributions}

MM carried out the experiments, performed the statistical evaluation and prepared the draft of the manuscript. JS accompanied the steps of the study related to lipid peroxidation measurement. $A L$ revised the final version of the manuscript. MK-L designed the study, supervised its conducting and prepared the final version of the manuscript. All authors read and approved the final manuscript.

\section{Acknowledgement}

The research was supported by a grant from the National Science Centre (polish abbr. NCN) to the Medical University of Lodz (Project No. N N401 539540). This study constitutes a part of Ph.D. thesis of the first author of the paper (MM).

\section{Author details}

${ }^{1}$ Department of Oncological Endocrinology, Medical University of Łódź, 7/9 Żeligowski Street, Łódź 90-752, Poland. ${ }^{2}$ Department of Endocrinology and Metabolic Diseases, Medical University of Łódź, 281/289 Rzgowska Street, Łódź 93-338, Poland. ${ }^{3}$ Polish Mother's Memorial Hospital - Research Institute, 281/289, Rzgowska Street, Łódź 93-338, Poland.
Received: 24 July 2013 Accepted: 29 August 2013

Published: 30 August 2013

\section{References}

1. Thilly CH, Vanderpas JB, Bebe N, Ntambue K, Contempre B, Swennen B, Moreno-Reyes R, Bourdoux P, Delange F: lodine deficiency, other trace elements, and goitrogenic factors in the etiopathogeny of iodine deficiency disorders (IDD). Biol Trace Elem Res 1992, 32:229-243.

2. Zimmermann MB, Andersson M: Assessment of iodine nutrition in populations: past, present, and future. Nutr Rev 2012, 70:553-570.

3. Pearce EN, Andersson M, Zimmermann MB: Global iodine nutrition: where do we stand in 2013? Thyroid 2013, 23:523-528

4. World Health Organization, United Nations Children's Fund, and the International Council for the Control of lodine Deficiency Disorders: Indicators for Assessment of lodine Deficiency Disorders and Their Control Programmes, Report of a Joint WHO/UNICEF/ICCIDD Consultation, 3-5 November 1992. Geneva: World Health Organization; 1993. Document WHO/NUT/93.1.

5. Bürgi H, Schaffner TH, Seiler JP: The toxicology of iodate: a review of the literature. Thyroid 2001, 11:449-456.

6. Rohner F, Garrett GS, Laillou A, Frey SK, Mothes R, Schweigert FJ, LocatelliRossi L: Validation of a user-friendly and rapid method for quantifying iodine content of salt. Food Nutr Bull 2012, 33(Suppl 4):330-335.

7. Murray MM, Pochin EE: Thyroid uptake of iodine from ingested iodate in man. J Physiol 1951, 114(Suppl):1-14.

8. Li Q, Mair C, Schedle K, Hammerl S, Schodl K, Windisch W: Effect of iodine source and dose on growth and iodine content in tissue and plasma thyroid hormones in fattening pigs. Eur J Nutr 2012, 51:685-691.

9. Zhu YG, Huang YZ, Hu Y, Liu YX: lodine uptake by spinach (Spinaciaoleracea L.) plants grown in solution culture: effects of iodine species and solution concentrations. Environ Int 2003, 29:33-37.

10. Voogt W, Holwerda HT, Khodabaks R: Biofortification of lettuce (Lactuca sativa L.) with iodine: the effect of iodine form and concentration in the nutrient solution on growth, development and iodine uptake of lettuce grown in water culture. J Sci Food Agric 2010, 90:906-913.

11. AFSSA: Avis de l'Agence franc, aise de se'curite' sanitaire des aliments relatif a' la modification de l'arre te' du 28 mai 1997 portant sur le sel alimentaire et aux substances d'apport nutritionnel pouvant e tre utilise'es pour sa supple'mentation; 2002. available: www.afssa.fr.

12. Poul JM, Huet S, Godard T, Sanders P: Lack of genotoxicity of potassium iodate in the alkaline comet assay and in the cytokinesis-block micronucleus test. Comparison to potassium bromate. Food Chem Toxicol 2004, 42:203-209.

13. Parsons JL, Chipman JK: The role of glutathione in DNA damage by potassium bromate in vitro. Mutagenesis 2000, 15:311-316.

14. Pahuja DN, Rajan MG, Borkar AV, Samuel AM: Potassium iodate and its comparison to potassium iodide as a blocker of 131 uptake by the thyroid in rats. Health Phys 1993, 65:545-549.

15. Joint WHO/FAO Expert Committee on Food Additives: Matters of interest arising from the forty-third World Health Assembly. In Evaluation of Certain Food Additives and Contaminants. Geneva: World Health Organization (WHO technical report series No. 806, Annex5; 1991.

16. European Commission: Commission Regulation (EC) No 1170/2009 of 30 November 2009 amending Directive 2002/46/EC of the European Parliament and of Council and Regulation (EC) No 1925/2006 of the European Parliament and of the Council as regards the lists of vitamin and minerals and their forms that can be added to foods, including food supplements. Official Journal of the European Union 2009, L 314:36.

17. Aceves C, Anguiano B, Delgado G: The extrathyronine actions of iodine. Antioxidant, apoptotic and differentiator factor in iodine-uptake tissues. Thyroid. in press.

18. Venturi S, Venturi M: lodide, thyroid and stomach carcinogenesis: evolutionary story of a primitive antioxidant? Eur J Endocrinol 1999, 140:371-372.

19. Küpper FC, Carpenter LJ, McFiggans GB, Palmer CJ, Waite TJ, Boneberg EM, Woitsch S, Weiller M, Abela R, Grolimund D, Potin P, Butler A, Luther GW 3rd, Kroneck PM, Meyer-Klaucke W, Feiters MC: lodide accumulation provides kelp with an inorganic antioxidant impacting atmospheric chemistry. Proc Natl Acad Sci U S A 2008, 105:6954-6958.

20. Joanta AE, Filip A, Clichici S, Andrei S, Daicoviciu D: lodide excess exerts oxidative stress in some target tissues of the thyroid hormones. Acta Physiol Hung 2006, 93:347-359. 
21. Sewerynek E, Swierczyńska-Machura D, Lewiński A: Effect of propylthiouracil on the level of Schiff's bases in tissues of rats on diet with different doses of potassium iodide. Neuro Endocrinol Lett 2006, 27:595-599.

22. Xia Y, Qu W, Zhao LN, Han H, Yang XF, Sun XF, Hao LP, Xu J: lodine excess induces hepatic steatosis through disturbance of thyroid hormone metabolism involving oxidative stress in BALB/c mice. Biol Trace Elem Res 2013, 154:103-110

23. Karbownik M, Lewiński $A$ : The role of oxidative stress in physiological and pathological processes in the thyroid gland; possible involvement in pineal-thyroid interactions. Neuroendocrinol Lett 2003, 24:293-303.

24. Karbownik M, Reiter RJ, Garcia JJ, Tan D: Melatonin reduces phenylhydrazine-induced oxidative damage to cellular membranes: evidence for the involvement of iron. Int J Biochem Cell Biol 2000, 32:1045-1054.

25. Karbownik M, Gitto E, Lewiński A, Reiter RJ: Relative efficacies of indole antioxidants in reducing autoxidation and iron-induced lipid peroxidation in hamster testes. J Cell Biochem 2001, 81:693-699.

26. Karbownik M, Lewiński A, Reiter RJ: Anticarcinogenic actions of melatonin which involve antioxidative processes: Comparison with other antioxidants. Int J Biochem Cell Biol 2001, 33:735-753.

27. Cabrera J, Burkhardt S, Tan DX, Manchester LC, Karbownik M, Reiter RJ: Autoxidation and toxicant-induced oxidation of lipid and DNA in monkey liver: reduction of molecular damage by melatonin. Pharmacol Toxicol 2001, 89:225-230.

28. Gitto E, Tan DX, Reiter RJ, Karbownik M, Manchester LC, Cuzzocrea S, Fulia F, Barberi I: Individual and synergistic antioxidative actions of melatonin: studies with vitamin $\mathrm{E}$, vitamin $\mathrm{C}$, glutathione and desferrioxamine (desferoxamine) in rat liver homogenates. J Pharm Pharmacol 2001, 53:1393-1401.

29. Karbownik-Lewińska M, Kokoszko-Bilska A: Oxidative damage to macromolecules in the thyroid - experimental evidence. Thyroid Res 2012, 5:25.

30. Karbownik M, Lewiński A: Melatonin reduces Fenton-induced lipid peroxidation in porcine thyroid tissue. J Cell Biochem 2003, 90:806-811.

31. Stępniak J, Lewiński A, Karbownik-Lewińska M: Membrane lipids and nuclear DNA are differently susceptive to Fenton reaction substrates in porcine thyroid. Toxicol In Vitro 2013, 27:71-78.

32. Karbownik-Lewińska M, Stępniak J, Lewiński A: High level of oxidized nucleosides in thyroid mitochondrial DNA; damaging effects of Fenton reaction substrates. Thyroid Res 2012, 5:24-32.

33. Milczarek M, Stępniak J, Lewiński A, Karbownik-Lewińska M: Potassium iodide, but not potassium iodate, as a potential protective agent against oxidative damage to membrane lipids in porcine thyroid. In Proceedings of the 15th International \& 14th European Congress of Endocrinology: 05-09 May 2012; Florence, European Society of Endocrinology. Edited by KB Bioscientifica. Euro House, Bristol; 2012.

34. Bradford MM: A rapid and sensitive method for the quantitation of microgram quantities of protein utilizing the principle of protein-dye binding. Anal Biochem 1976, 72:248-254.

35. Leoni SG, Kimura ET, Santisteban P, De la-Vieja A: Regulation of thyroid oxidative state by thioredoxin reductase has a crucial role in thyroid responses to iodide excess. Mol Endocrinol 2011, 25:1924-1935.

36. Li Q, Mair C, Schedle K, Hellmayr I, Windisch W: Effects of varying dietary iodine supplementation levels as iodide or iodate on thyroid status as well as mRNA expression and enzyme activity of antioxidative enzymes in tissues of grower/finisher pigs. Eur J Nutr 2013, 52:161-168.

37. Taurog A, Chaikoff IL, Feller DD: The mechanism of iodineconcentration by the thyroid gland: its non-organic iodinebinding capacity in the normal and propylthiouracil-treated rat. J Biol Chem 1947, 171:189-201.

38. Taurog A, Tong W, Chaikoff IL: Non-thyroglobulin iodine of the thyroid gland II. Inorganic iodide. J Biol Chem 1951, 191:677-682.

39. Tiran B, Karpf E, Tiran A, Lax S, Langsteger W, Eber O, Lorenz O: lodine content of thyroid tissue in the Styrian population. Acta Med Austriaca 1993, 20:6-8.

40. Kuzmuk KN, Schook LB: Pigs as a Model for Biomedical Sciences. In The Genetics of the Pig. 2nd edition. Edited by Rothschild MF, Ruvinsky A. Wallingford: CAB International; 2011:426-444.

41. National Toxicology Program (NTP): Toxicology and carcinogenesis studies of sodium chlorate (CAS No. 7775-09-9) in F344/N rats and B6C3F1 mice (drinking water studies), Technical Report Series no. 517. NIH Publication No. 06-4457. Research Triangle Park, NC: National Institutes of Health, Public Health Service, U.S. Department of Health and Human Services; 2005.
42. WHO/IARC: IARC Monographs on the Evaluation of the Carcinogenic Risk of Chemicals to Humans, Vol. 40, Some Naturally Occurring and Synthetic Food Components, Furocoumarins and Ultraviolet Radiation. Lyon: WHO/IARC; 1986:207-220.

43. Karbownik M, Stasiak M, Zasada K, Zygmunt A, Lewinski A: Comparison of potential protective effects of melatonin, indole-3-propionic acid, and propylthiouracil against lipid peroxidation caused by potassium bromate in the thyroid gland. J Cell Biochem 2005, 95:131-138.

doi:10.1186/1756-6614-6-10

Cite this article as: Milczarek et al.: Potassium iodide, but not potassium iodate, as a potential protective agent against oxidative damage to membrane lipids in porcine thyroid. Thyroid Research 2013 6:10.

\section{Submit your next manuscript to BioMed Central and take full advantage of:}

- Convenient online submission

- Thorough peer review

- No space constraints or color figure charges

- Immediate publication on acceptance

- Inclusion in PubMed, CAS, Scopus and Google Scholar

- Research which is freely available for redistribution
Ciomed Central 